\title{
CONSIDERAÇÕES SOBRE UM ELEMENTO ÉTICO NO MEIO DA DIALÉTICA NEGATIVA
}

Marcia Tiburi*

StNTRSB - Bsto teocto consiste nama teotativa de compreender a Dalkicica Negativa de Adorno, atravis da questlo de "Vetorone", isto ह̇, da perda no procesaso bistórico, social e lógico. A "Vealocene" como "a perda" e que fundamenta a concepçio geral de distitioa negativa em oposiçbo a diabtica pcoitiva, que opera com uma concepcto do "Authebung" positiva. O tesco procurn desenvoiver uma ideta de "Authobung" negativa, capaz de ser corsiderada como um elemento 6 íco na dialticion.

PALAVRAS-CHAVB - Dialetica Negativg, Adorno, "perda", Atice.
ABSTRACT - Thit tox try understand the Adardo's Negative Dralectic through of the questico of "Verlocene", that is loet in the historical, socinl and logical process. The "Veloreos" as "the Last" is that found the general conception of negative dialectic in opposition to the poeftive dialectie that work with a cooception of posittive Authebung. The text soarch to unfold an idea of nogative Authebung ablo to be considered as a ethical elemert in the dialectic.

KEY WCend - Negative Dualectic, Adarba, "Verloreos", Buhic.

\footnotetext{
"O pecsameeto sguarda que, um dia, a lembeança do que foi perdido venha deeperta-10 e o transfoeme em ecsinamento." (Aderno, Minima Maraila')
}

A complexidade da tarefa relacionada da apresentaçăo de um conceito de dialética negativa define-se através da sua necessidade histórica capaz de confundirse com uma necessidade didática nascida da tracessiblifdade conceitual do texto de Adorno que leva este nome. Tal inacessiblidide desperta de uma real dificulCade na compreensǻo da sua escrita e das questōes que all estáo postas, o que nầ constitui um argumento para que ele nẩo seja enfrentado.

- Professoxa de flosoba (Ceatro Bducacional La Suile de Brsino Saperior e Uniwersidade do Vale do

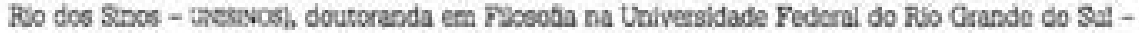
Uracos.

1 Adorna, Theodor W. Minima Moralis. Refexoonan aus dem beschldigten Lebcn. Frankfurt OM: Suhrkamp, 1973. p. 101. -Dor Godonko wartot daraul dess eines Toges die Erinnerung ans Ver-

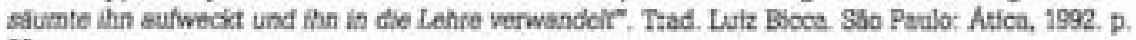
no.

\begin{tabular}{|l|l|l|l|l|l|}
\hline VRRTIAS & Peeto Alegre & v. 43 & $n^{2} 4$ & Dezembro 1998 & p. 1031-1052 \\
\hline
\end{tabular}


De fato, não é possivel simplesmente tentar traduzir o pensamento de Adorno, - que não se realizaria nem através de um inventário das definiçũes sobre dialetica dadas por ele mesmo ao longo dos seus textos, até porque Adorno é um severo critico des definiços enquanto constructos fechados e sufictentes em si mesmos. Portanto, o texto que segue resolve ponderat a possibilidade de compreender - o que nẫo implica simplesmente definir - a daalética negativa como uma dia'ética da perda, ou soja, que rompe com a idéla de guarda e superaçăo caracteristica da Aufhebung hegeliana, trabalhando com a ideia do que se poderie chamar uma Aufhebung negativa. Há que se pensar, neste caso, sobre o elemento ético presente na negatividade da dialética, o que leva à consideraçào de que uma tal dialética estrutura-se para além de um registro logico, sob uma base historica e social. E, assim, o próprio concelto de fllosofla altera seu sentido.

\section{A transformaçăo da filosofia, a historia e a perda}

Considerar a própria idéia de uma dialética negativa remete à questão de uma transformaçäo da própria dialética sempre pensada sob o signo da positividade. No bojo desta questão aparentemente apenas conceitual se tevela uma outra, a da transformaçăo da própria filosofia ${ }^{2}$ ciente de sua crise posta na consciência da

2 Karl Otto Apel no acu livo $A$ transformaço da Slosctia (Traraflormadion der Philoseghie. Frankfurt

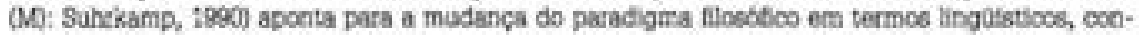
siderando qoe uma transformaça da flosotia se daria nos termoe de uma flosotia transcendertal fundsda no a priori de uma comunidade de comunicaglo que sesia ums resposta a perpunts pelas condiçbes de pocsiblidade e validado das convorpobes e como uma fandamentaçto siltima da filosotia pratica e tedrica e da citencia. Ha que se pcoderat que esta transformaço deeocresdera ums transformacilo substancial jo pocta no caminho de realizaclo pela Tecria Caitica e que preocupa-ae atsda, contrariando muito especikcamecte a cossideracho apeisna de que 80 pode espera posco de uma flosofia totalmente engejada politicamente, a necossidade de transformat a vida social - o que constitul uma atitude poitsca erpocial - para alóm do uma transformaclo apenas po nivel da linguagen que necessita de uma antectpoplo contrafitica de conserse para justiboat sua própria

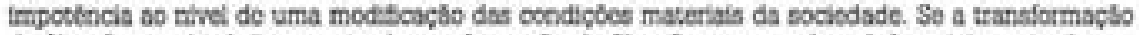

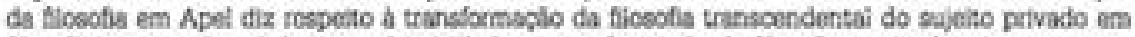
Elosotia transcendental da intersubjethidade, s tansformaça da tiosctia que so bueca compreender no Ambito da tecria citica, e que Ademo leva a termo de am modo muito produtivo como se mostrart ao longo do toxto que sergue, diz respeito ainds a necussidade marxians de transformar 0 mundo concreto, de fazer da flesobs algo mals que mcro discurso, neste caso, fazet dela um tipo de interptetapâo que, a partir da transformscilo de sit mesms, seja capar de scabat com a falsa conocitncia, carninho para a transformaçlo da socledsde. His que se conceber, no imbito destas considerap̧bes, como a propocta da tecria critica ainda nầ foi suficientemente compreendida em seca argumentos o posicbee. Habermes tamberm pensa a traneformaç5o da teoria critica enquanto a lntegra a a ambito das cièncias e so peradigma da linguagen e da ética do discurso, transiloema.

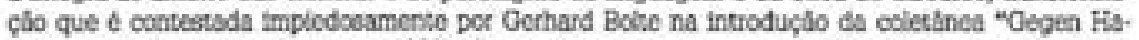
bermas" (Läneburg: za Klampen, 1989) aftrmando com as palavias de Horkheimer que sa teoria cri. tica quer "a emancipaplo do homem das relapoles escravizadoras" (p. 7), mail do que simples. mente promover outta pedxis cientifica comso quer Habermas, quem, alibs, para Boltes, reconstrct maito mal a tradiçlo (Kant, Hogel, Maxx, Engole, Netzoche, Freud) a partir da qual a Tooria Critica se reconstrof encuanto so esconde atras ds sociologia burguesa de Weber e Durkheim e da tecria de sistems e aç5 de Mead e Parsons. Assim haveria que $\infty$ pocderar sobre a teal necessidade de uma mudance de pecadigma, como faz Anke Thyen (Negative Dialektik und Brfahrung. Zur Rationahtel des Nicheidentischen bei Adorna Franktart (MA) Suhrkamp, 1969. D. 127, considerando, por coempla, a questlo da reconcilisclio (Versohnung) como um fundamento da tociris, que rilo pode ser vista simplosmente como entendimento. Sobre este tersa hí um capitulo mats as tenal doste texto. 
tenşăo entre teoria e prática. A necessidade de uma transformação, contudo, se pôe para além de uma moúlificaçâo de paradigma que se faz passar, neste final de secculo, como a melhor alternativa para a filosofia. Antes haveria que se rever as circunvoluçōes daquela relaçăo tensa entre teoria e prática ponderando a própria necessidade de uma revisāo da flosofia que começa com a critica ${ }^{3}$ da dialética e da racionalidade. ${ }^{4}$ Há que se compreender o que seja uma transtormaçalo da razão considerando a existùncia de uma "razßlo potencial"5 capaz de apontar para uma transformaçầ da tilosofia a partir de urna critica que pretende, por sua vez, uma transformaçäo da vida na sociedade, ${ }^{6}$ na medida em que se faz como soluçăo concreta de problemas passados e năo sua substituiçâo no contexto d e uma mudança de paradigmas,? e que ainda pretende a valorizaçăo da teoria como forma de práxis transformadora. ${ }^{8}$

Bsta seria a primeira questão a ser colocada quando se discute no ămbito fllosófico - na escola de Habermas - o problema da intersubjettvidade e da comunicaçẩo como pretensas solup̧ēes para os problemas éticos e gnosiológioos. que

2 Segundo Aderno, "o pensar fllosdbco satisfationo \& critica no so tronto as existente e d sua moldsgem coisal ha consolíncia, mas tambeim, na mesma modida, frente a si mestmo". Observapoles sobre o pensemento fllositico. In: Palavras e Sinats. Modeles Criticos 2. Petrobolis: Vores, 1995 . p. 23.

4 Ha um tecto de Dte Guzwod "Ressan - A Diflerent Rasson - Samething Diflevent Than Reseon? Wondering about the Concept of a Ditforent Reasco in Adorna Lyotard, and Slsterdipk" In Pensiky, Mex. The Actuelity of Adomo. Critionl Besays on Adoeno and the Postmodern. Scese Unitwesity of Now york Preas, 1997.] tenta ver a tolaçlo cotre uma "razlo alternativa" o o "conceito de Raciosialidade" em reloçlo acs seres humancs $\theta$ a natureza. Distinguindo de um modo interesearte terdo (Vernunft, Nous, noein) de tacionahidade (Rationelitat, Diancia) - a primeita como caracteriatica do esciarecimenta, algo escrtente e inetiminivel e a segunda como o modo cono a razlo se ple na sociedada - o texto tenta mostrar que o interesse de Adorno está na tacionalidade. A partir de Adorno se poderia pensar uma racionalidade que deixa o objeto talar (o. 33 ) sendo pot ele determi-

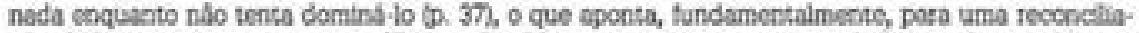
clo do homem com a natureza. Uina razáo diferente, neste conteoto, serla capaz de unir Novs e Diandla, razlo o petcepclo e tambem senselolliade (p. 40).

5 ND. . 311

6 Neste ponso seria incereasante o eetudo de Peter Moctrz Kitik des Paradigmenwechals: mit Hoekheimor gegen Habermas (Luneburg: Zu Klampen, 1992), gue aponta para uma reconstrucilo do pensarescto de Hickheirser oboervando o sed potenctal eribso no morecnto de uma traneitotmaclo da teotia crítica que apcota para nlo apenss uma ádto critica da tecria que se quet ciênecia, mas inclusive das consectuencias petticus teistivas a necossidade de meihorar as condipbes de vida da humanidade que nascem desta auto crivica. Bm Horkbeimer a transtormaplo da fllosofia e uma transformacbio da prdics. A flocoka a partir de Hotkheimer (eonsiderando seus primetrce textos sobrewodol nalo poderin ser um mero eacercicio acadtenico, nem apenas pessimismo com acentes tecibgloce. Ver p. 11)

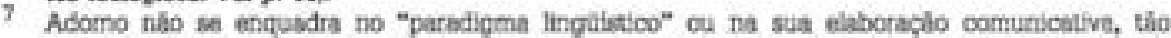
popularizado na Teoria da A plo Comunicativa do J. Habermas (p. 499-539), porque Adorno crilca a ideta de comunicaçác. Ao mesmo tempo, ndo é posatvel considetá-lo um partidirio de um pera-

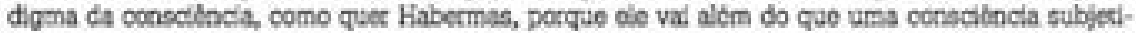
va pode pxoblematizar tornando-80 sea critico A bese de tal consldecaçío sparecers mals adiante. Habermas teclsma gue Adocro fea por demeis fixado, dentro do paradigma da consetencia, is telaches ectse a subjetividade e a auto conservaclo $(\mathrm{Op}$. cit. p. 490\%, Habermas cad no mesmo erro que Adorno coofere a Hegel: soivetonar os problemas petitcocs atravits e elo-somente no melo do persamento, o que ele fax ao confundir o ideal e o teel, o semalntico e o prajgmático

- Contreriamonto ao decmentir da protecoslo tocrtetea atrants da critica da razjo instrumental como quer Habermes. (Theorie des kommunikativen Handelhs. Frankfart[M]: Suhrkamp, 1989. B. L, p. 528. 
afetam o ser humano na sua busca pelo saber e pela melhorla das condiçð̇es de vida Na margem desta problemática alguma coisa parece estar sendo esquecida enquanto parece ter sido superada. Será preciso ver a validade de uma critica imanente baseada na negaçäo determinada ao chamado paradigma da consciencia, sem seu abandono ou sua substituiç̧̃o por parte do chamado paradigma da comunicaçầ que pretende tê-lo suprassumido. A flicsofia prectsará repensar o ser conceito de sujelto e de objeto e o potencial de liberdade presente neles e inviávels no conceito de comunicaçăo.

A consideraçăo acerca da Dialética traz à tona uma conceppāo de história da filosofia, ela apenas teria sentido enquanto busca retrcspectiva do que foi abandonado ao esquecimento, do que foi negligenciado, daquilo que compde o insconsciente da filosofia. Contudo, tal busca histórica năo pretende cair na questáo heideggeriana do "Ser", ele também esquecido, contra o qual a filosotia de Adorno se insurge; trata-se, antes de compreender o que escapa a ontologia enquanto é perdido na ordem da vida concreta e cotidiana. Caberia compreender porque a Dialetica Negativa é uma ontologia da situaçato talsa.

Neste caso, se há uma "História" hegeliana, ${ }^{10}$ maiúscula, capaz de ser escrita como evoluçăo e totalidade, ela será medida pela chance de sua falsidade. É o conceito de história da fllosotia que precisa ser alterado, portanto, compreendido em suas posiçóes menos visiveis, mass avessas, para possiblititar uma compreensăo do conceito de filosotia a partir de uma outra base. A questão serb́ ponderar a possibilidade do pensamento e do conhecimento no campo filosófico - e fora dele - considerando o fato de que há uma história cristalizada como verdade que precisa ser compreendida a partir do que ela mostra e do que ela esconde. Ê preciso, nesta tentativa de repensar o que seja uma historia da fllosotia, retornar ao conceito de histćria natural, capaz de apontar para aquele substrato perdido. 0 conceito de historia como natureza diz respeito ao que foi perdido e ao mesmo tempo está guardado, sem ter sido superado, sendo, portanto, guardado como um vazio. $\hat{B}$ isto que se pode chamar de uma Aufhebung negativa. $O$ conceito de história natural na forma como Adorno o trata apresenta-se com um certo carảter hermét$\mathrm{co}$; a leitura dificil do texto que carrega esta expressä $0^{11}$ talvez sirva para indicar a próptia complexidade da reunilio de elementos opostos por sua própria definiçăo mais imediata. História seria o oposto à natureza e Adorno quer integrá-los. Se, de um lado, esta reunião parece forçada, de outro ela será ousada enquanto elimina a idéia de um espirito que existiria para além da natureza, fazendo dele uma parte daquele mundo que ele buscaria superar. $\mathrm{O}$ espirito perderia a sue aura ao ser compreendido por sua dobra orgânica e instintiva. Mas Adorno nâo pode definir história e natureza de um modo direto. Bsta última representa o mítico, o sempre o mesmo e é o que sustenta a história humana que, por sua vez representa o novo. Para ele, como aparece no texto sobre a "A Idéia de História Natural", a questão serla conceber a histórla como natureza e a natureż como histórla. Este conceito

S. E o que ocorro em Habermas, Ver Theorie des Kommunikativen Handeins B.I p. $522-523$.

75. Ver a Filosofia da Fistoria de Hegel, coetta a qual esta coocepplo se constró. Trad. Maria Rodrigucs o Hans Harden. Bracilis: Bd. UNB, 1996.

11 Dio ldee der Naturgeschichte. In Ptilogophische Fraschritten. B. L. Frankfurt (M): Surhkamp, 1990. 
é devedor do conceito de segunda natureza que aparece na Teoria do Romance de Lukács sendo incorporado por Adorno. A segunda natureza diz respeito ao mundo da convençăo, das coisas que se fizeram alheias, que nâo podem ser decifradas e nas quais se tropeca enquanto elas aparecem como cifras. Adorno aponta a questh̉o fundamental de Lukács: como è possivel conhecer este mundo alienado, colsificado, morto? Pergunta que terla algo de espentoso no sentido da admiraçăo

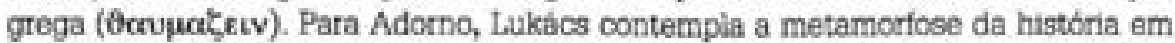
natural, a história paralisada é natureza ou o que é existente na natureza paralisado é um mero ter sido histórico. Lukács fala de um despertar do sentido aí como possibilidade metafisica e adere da idéla de ressurreiçăo. $O$ que interessa a Adorno $\hat{e}$, entî̄o, justamente a idèla de um despertar do cifrado e do paralisado. $\hat{\mathrm{E}}$ nestes pedaços - perdidos do todo - çue se construirá a idéta da constelação, 6 a partir deles a idelia de uma materialismo metafisico emetgirá mais tarde. A transcendência aparecerd na idéla da Verganglichkeit, que une o caráter de algo passado, da caducidade, da transitoriedade, opondo-se, portanto, ao imutavel, absoluto e universal. História natural é também segunda natureza porque se constró por sobre a primetra, $e$ as suas custas, e permanece tendo suas características: a histótia como cultura nấo eliminou a natureza e perpetua o ciclo do seu domínio.

O que se pòe em jogo, neste caso, é o sentido da expressáo Aufhebung enquanto ela possa interferit em um conceito de história como dialética. Ao contrário da dialética hegeliana que se constról no jogo do superar e guardar (Aufhebung), a dialética negativa viverá sob a imagem do que se perdeu, nảo tendo sido nem guardado, nem superado. A suprassunçăo, embora exista na dialética negativa, é inconclusa enquanto năo se verifica na prática e é aquilo que deve ser buscado embora năo possa jamais ser garantida, nem realizada no todo. Bla consiste naquela forma do pensamento que nẫo tem pretensăo alguma de possuir o que fol perdido (das Verlorene). ${ }^{12}$ E neste sentido que se concebe que a negação da negaçăo nẫo se transforma em posittividade.$^{13} \mathrm{Na}$ dialética negativa, 0 conhecimento deve se voltar para o que nấo se inseriu, não se enquadrou, segundo Adorno, na dinalmica da história nem como vencedor nem como vencido, para o que, nas suas palavras, são os "residuos e pontos sombrios que escaparam à dialética". "14 Contra a Aufhebung a filosotia de Adorno vive sob o peso daquilo que se transtormou mesmo em uma metátora: Auschwitz pode ser considerada deste modo. É ela que decide o rumo que uma dialética toma definitivamente até que a injustiça possa, quiçá, ser reparada. Al aparece uma caracteristica fundamental da fliosofia de Adorno que a vincula diretamente ao materialismo em um sentido maxxista: ${ }^{15}$ a

12 Nogative Divektik p. 385

13 Negative Dialekel . D. 385

14 Minims Maralis. p. 290

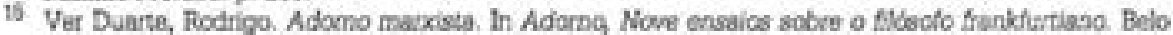
Hocizonte: Eostora UPMG, 1997. D. $109-115$ o Gerhasd Bolte Veen Maxx bis Hericheitnec. Aspebse kritiectbe Theorie im 19. und 20. Jehuhundert. (Durmatadt: Wiss. Buchgcs, 1995). Ambca ce teecos tectan mostrat a flliacto de Adorno, no caso do peimseico, e da Tectia Critice encuanto tal, no segundo teseo, ds conquistas do pensartento mancieno, Bote, por exemplo, afima val filapilo mostrando como a Tocria Critica pretende ums transformaçlo da flocota em tocria da sociedado e ace mesmo em critica da economis politica, que a sua presensblo escapa as simples fendeneno local, 
sua solidariedade com a miséria do mundo, com o sofrimento humano nascido da exploraçđ̆o e da violência.

Ble indica como a filasofia e a sua história podem ser pensadas, como ela precise recuperar o que deixa para trás como ruina ao longo do seu processo históni$\infty$. B, neste caso, para lembrar Proust e Benjamin, há que se ponderar que o processo de avanço real da filosofia teria que se abeberar até mesmo de uma memória involuntária, reconhecendo e incorporando sua experiência, ou seja, a fliosofia acabaria por se tornar mais completa ao aproveitar experièncias nalo definitivamente conceituais, neste caso, de lembranças ainda nâo dominadas pela racionalidade discursiva: ela poderia se valer do ato de lembrar o que nåo se tornou objeto de histócia. Nisto residiria a possibilidade, necessária à filosofia que se pretende repensar auto criticamente, de chegar ou pelo menos considerar o que lhe está oculto enquanto aquilo mesmo que a forma. A filosofia de Adiorno, neste momento, è aquela capaz de apontar para um momento subterrâneo à fllosotia: ela traz à presença a problematizaçäo do significado do que foi perdido, e que serla a expressão negativa, mise en scène do próprio negativo da sua história.

A transformaçăo do conceito de fllosofia quando pensado na perspectiva do que fol sua história define o fato de que esta história se torna seu objeto e al entra em questão também o significado da fliosofia a partir do tratamento que ela, enquanto atitude da consciéncta, da ao seu objeto: neste caso, como ela mesma o conceitua. É, portanto, na face de seu objeto que ela é capaz de pensar a si mesma. Por isso, enquanto o seu conceito apenas pode ser compreendido de um ponto de vista de sua história, ela precisa de um lado, compreender melhor a si mesma enquanto se toma como seu próprio objeto; de outro lado, ela precisa problematizat tambem o conceito de objeto. No registro da Teoria Critica, dentro da consideraçăo de que algo é perdido para a filosofia e para o conhecimento que ela ajuda a fundar, este algo é justamente o objeto, e que é às custas dele que a subjetivldade se faz totalitária até a perda de si mesma. A perda da subjetividade será uma consequêtncia da perda da capacidade de pensar o mundo objetivo, quando ela é concebida e age como algo independente do real ou anterior ao real ou capaz de simplesmente produzi-lo.

De um lado a questăo da perda enquanto idéia ou mesmo categoria diz respeito a um problema interno à fllosofia pondo em evidéncia o seu caráter relativo á uma determinada epistemologia, de outro, ela diz respeito a uma questão humana que a filosotia precisa considerar para ser ainda algo humano, algo que busca superar a barbárie no contexto da vida social. A própria filosofia, neste caso, não se poderia ver envolvida apenas com suas próprias demandas internas de um modo imanente - quando ela se tornaria uma eterna tautologia na ordem de um

que nbo se trata de uma mera trademark, mas de uma tecria ocupeda com um modo de persar fundamentads no materialisero histénco e na tecria sodal econemica. Adorno, embora critioo, permaneceria nlio apenas tributhrio da tectia do Maxx, mat tamblem seu cootinuadar de um modo sutl. Altred Schmidt em "Adomo - ein Phulasoph des realen Humaniamus" (In Thoodor W. Adorro zum Gedschtris. Org. Schweppenhusser. Trankfurt: Suhrkamp, 1971) relaciona o que ele coscebo cotno o humanismo de Adorno com o conceito marxesta de humanismo resl CSagrada Fanilis, 1845. ou soja, aquile que nbo roduz a bumanidade - o ser hamano concreto - 00 cenceito do auto-conscilncia e espirito. 
dialogo com sua propria história incapaz de perceber as conexठ̋es externas af implicadas - mas percebenia nestas demandas concxibes socials e politicas que farlam da teorla - enquanto the dão o seu modo de localizar-se no mundo - um elemento solidário aos problemas práticos do mundo que envolvem seres humanos em suas relaçōes sociais e suas relaçles com a natureza.

Uma transformação da fllosotla que se propōe a um retorno crítico ao passado, quer reavivar a negaçăo determinada, a bestimmte Negation hegeliana," como um elemento constitutivo do próprio concelto de filosofia. Nisto é evidente, na teoria adorniana e na teoria critica, a demonstração de uma corajosa "resistência" à tăo famosa mudança de paradigma por considerar (o que se pöe como uma das necessárias consideraçóes sobre a fllosotia de Adomo e que exigem que ela venha a ser lembrada com urgêncla) que não há trabalho fllosófico longe da história da fllosofia, e que, radicalizando esta idéia de Adorno, que esta história ainda năo fol totalmente contada, nem definida, nem o será, e que é a consciência da existência destes lados contrapostos da histótia, que dảo sentido á critics, a qual só pode ser realizada neste confronto. A possiblilidade de uma auto critica da filosofia estabelece-se al enquanto é modificado o seu próprio conceito que acabará por envolvê. la com o espaço eminentemente prático da atividade humana.

A questlo, portanto, e a compreensăo da diferença existente entre uma transformaçāo da filosofla dentro da tradiçăo ${ }^{17}$ - sua simples moditicaçăo ao nivel da sucessto das teorias - e a ocorrida com o advento da teoria critica que rompe com a própria tradicalo para instituir-se, embora apenas venha a ser possivel através da força propulsora daquela mesma tradiçäo que ela busca negar, todavia, determinadamente. Transformá-la negando-a, deste modo, segundo o próprio Adorno, é a única relaçăo que a filosofia pode ter com a tradiçầo, ${ }^{18}$ Neste sentido, a teoria critica seria a efetivação de um potencial de alguma forma presente na teoria tradicional ${ }^{33} \mathrm{e}$ a sua especificidade residiria na capacidade de recuperar a

16. Hegel, Q. W. F. Phalnomenologie des Geistos. Werke. B. 3. Frankfun(M): Suhtkamp, 1966. D. 74.

17 Adoeno ao faliar de um atentado a tradiçalo que a Dialetica negutiva é, usa o turmo Oberlieferung OND. p. 9\%, ao falar de ums tradiclo que clio poderis ser atocade simplesmente porgue faz parto do próstio conbecimento ele usa o termo Tradition (ND, p. 63.61). Uberlieferung dit respeito a trarsmisabo ds cuitura. Trodition 6 um termo mals lyado a Geschichte, enfatizando o modo corro elementos oukurais se deservaivem histcricamente e rbo apecas como se da sua transmisedo.

si Negative Dialicktik. p. 64

12 A expresslo "toocia trodicional", constantemente utilizada neste texto, tornou-se um classico noe estudos em toeno da Teccia Cetica, a qual pretende set a oposto definitivo, pcrèm dialetico, da. Guela ferma de toorla. A expresslo fas parte do titulo do bumoso artigo "Tradidianello und kritioche Theorie" de Max Hockheirser, pubticado pela primeira ver no Zeitschuth fuir Sorialiforsebung, 6 e 1937, cujas cocsidesaçbes s\$o amplamente compurtinadas pot Adorno, podendo-ae, ate mesmo. dizer que a dialf́tico negativa seria s conseqleincia svancada do que se alcanca sob a forma da to. oria critica. A csto propositto, o pebptio horkheimcr no sou tescto -Sobre o pecoblema da verdade de

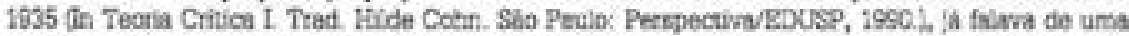

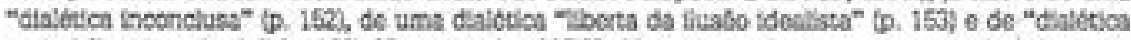
materialista inacabada" (p. 168). No artigo de 1937 Horkbeimer expóe o que eile entende pelo modo de existência da teccia em sentido tradicional, vineulando-a so sentido da cilncia no zundo moderno sobeetudo na forma da exeglencias cartestanas para a consolidaplo da verdade de tooria apresentadas no Discurso do Mcrodo. Horkheimer quer, certamente, referti-se a toda a tradicto que nesce com as próprias pretersobes da cievcta estendidas a tode forma de teocin. Assim, para falar resumidamente, Hockheimer critica desde a matemoticidodo, a logica implactive, a bipdotase 
verdade latente dentro daquele contexto, aquela que restasse, de certo modo, após a critica. A flilosofia transformada que se apresenta no pensamento adorniano năo se pretende instituir como algo totalmente nowo que parta de um ponto origlnal - por isso Adorno volta sempre a Hegel ${ }^{20}$ e a Kant ${ }^{21}$ - e substitua a precedente. Trata-se, portanto, de uma filosofia elaborada a base de uma critica imanente capaz de fazer aparecer o potencial emancipatório da própria tradiçăo. Esta espécie de critica é que salvará a relação entre a teoria tradicional e a tecria critica que, no caso de Adorno, se fará sob a forma da dialética.

Tratar-se-ia, ao fundo, de buscar uma resposta à questão dificil: se a filosofia pode permanecer sendo apenas trabalho acadêmico ou se ela deve transformar o mundo, o que implica iniciar pela reformulação de si mesma.

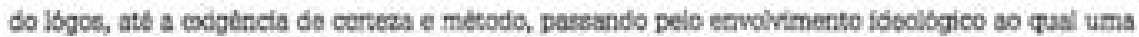
tal tecrin acabe por aceder na medida em quo desconsidera ess relaçöes socials nas quals se envolve. Por opceicla, a tecra crides dove ser aquela, cujo peneamento "comprocnde a si mesmo como hipotese e nilo como cartars" (Trad. bras. p. 49). Segundo o probcio Horkheimer "o pensamento critico é motivado pela tensativa de superar roalmente a tenebo, do eliminar a cpoesplo entzo a conscilocia dos objetivos, espcctaneldede e rocionalidade, increntes a individuo, de um lado, e as relaples do procosso do trabalho, bleicas para a sociodade, do cutro. O pensamonto critico contém um conceito de homem que contraxia a st encuanto năo ocorrer esta identidade. Se ê pròpeio do homem que eeu agir soja determinado pela razlo, a pradis social dada, que da focma so modo de ser (Dasein), é defumana, e essa deaumanidade repercute sobre todo o que ocorre na sociedade". (p. 46) A Tecria Critica, deste modo, esta detinirdo sua deccontianga em reloglo a razso (ela scabs com o mito da certeza tacianal do cual vive a ciència) o d sociedade raciconalizada e odranistrads, descontianga que permoard toda a teccla de Adorno. A qucotalo que interessa, no entanta, 6 comproonder qusis as ctrcutruchapbes da teoria adorniana en relaçlo a esta sua foete primordial e como els se transforma para slem desta que 6, por assim dizer, sus pátria. Para um histrírico da teoria crikica e da chamada Bscola de Franikfurt ver Buck-Morss, Susan, Origcm de la

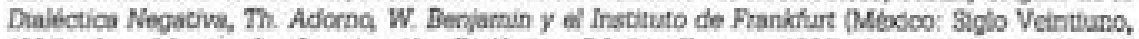
1961) Jay, Martin, La Imogtnscion Dialdetica Gadri: Taurus, 1996), Wggerhaus, Roth, Die Frankfurt Schwle (Munctea/Wen, 1986 Trad. ingiesa The Frankfurt School. its History, Thoorics and Political significance. Cambridge: The Mit Ptess, 1995) e de Hoseth, Axel, Kritik der Mecht Reflexicnsstufen etber kntischen Gesellschaftstheorie (FrankiturtaM): Suhckamp, 1990. Ver tambem Peter U. Hohendel. Prismacie Thought. Theodor W. Adorno. Univ. of Nebraska. Press, 1997 e uma pequena biograta que 6 tambim uena intectaclo ao pensamento de Adcrno, Ireikulads "Adorno" CHamburg: Rowohis, 1989) do H. Schefblo.

20 Ver Demmering, Christrpt. Prallosoghile als Kritik. Grundprobleme der Dialoktik Hegel und dos Programm kntiecher Theorie. In Vernuntikntik nach Hogol Aaslytisch-kaitische finterpretation zur Dialcktik. Org. Demmerling, C. e Kambartel, F. Frankfart (M): Suhrkamp, 1992. P. 67.

21 A filosotia de Adoeno seth tributatis da tradiçso kantiana (o pectpeio Adorno pereco estipular tal

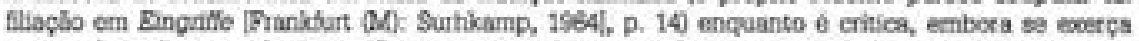
contra ela e, deste modo, intunsifque o pocendial inasgurado e, por outro lsdo - segundo Adorno interrompido pelo proprio Kant. Ao lado de Hegel, Heidegoer, Husserl, Kant ocupou um espaco de discussalo tundamental em Adorno. A ele é dedicado o primeiro dos trts modelco apreoentadics a Dialitica nogotiva, intetulado "Zur Motakritik der praktischen Vernunf", p. 211-294 (Prankfurt (M): Suhkamp, 1962). Fredrie Jamescn (O marxisme tardio. Adoeno, ou a persigtlocia da dialética. SP: UNDSP/Bottempo, 1997.p. 101-104 demonstra como a Dialetica Negativa se cstrutura com base nos testos kantianos, no caso a Critica da Pazlo Para, e mesmo a imita, o que faz com que Adorno nlo possa, enquanso ensalets, ser levedo ao pe ds ietta, locnando tanto mais becessiria uma compreensáo da sistematicidsde lógica dos seus escritos pelo menos no que se refere oo seu espectalzado e como que, por verts, subteredneo ditlogo com Kant. 
A filosofia de Adomo tem uma tal perspectiva quando fala de uma filosotia modificada ou transformada (verändorte Philosophie) ${ }^{2}$ que abdica da crença na possibilidade de possuir o infinito tornando-se ciente de seus limites enquanto é capaz de tomar o semelhante como o que náo se assemelha ${ }^{23}$ rompendo com a violência đa identificaçăo. A idela desta transformaçăo também está presente quando ele fala de um pensamento não ingểnuo $0^{24}$ capaz de critica e auto crítica $e$, do mesmo modo, quando diz o que a filosofia deve ser por pertencer à esfera do insubmisso (Ungebändigten), ${ }^{25} \mathrm{o}$ seu espirito revolucionário, portanto, daquilo que nẫo se conforma com o que $\mathrm{e}$, com o existente que se configura na forma-mor da Ideologia enquanto consciéncia falsa, ${ }^{26}$ Fundamentaimente, ainda quando afirma uma mudança qualitativa da dialética (de uma dialetica modificada ${ }^{2}$ ) em funçð̄o do abismamento inconsciente da consciência frente acs fenơmenos, ${ }^{30}$ o que levaria ao que ele chama um pensamento capaz de frutificar, ${ }^{20}$ aquele que possa sair do cublculo de sua própria construção e chegar ao real a partir do qual o pensamento é construído.

Há uma relaçäo de sinonímia entre cialética e critica em Adorno. Se a dialétca negativa é a forma de conhecimento nescido na relaçăo entre opostos que năo se resolvem numa sintese alçada sobre eles como verdade, a critica será a própria pergunta pelo conceito desta verdade. Portanto, a dialética negativa é a modificação qualitativa da dialética que se faz como critica. Se uma cialética crítica é aquela que desmonta o conceito de dialética tradicjonal, uma critica dialética é aquela que sabe ver a verdade do que fot desmontado.

Que a filosofia seja critica exposta sob a forma do ensaio só será possível através da aìteraçâo do sentido do pensamento que inicja pela análise da sua condiçẵo

22 Negatiwe Diaiektuk, p. 25 e 153

2. Negative Dialcktik. D. 153.

24 Negative Dialektik. p. 26.

25 Negatwo Dialeitik. p. 26 .

as Gucrua Tong faz vor em seu livro Dialektek der Freiheit als Negation bel Adorna. Zur Freibeirakonzepeion der negativen Dialektik (Manster: Lit, 1805) que, de fato, nào hà nenhum progresso consideravel no conceito de sdeologia que Adocno tha de Marx e que a dotine come a conscibncta falsa, as roloposes sociais falses e, por fim, a apatlocia social construida pelo intertesse de uma ceterminade classe (p. 39). Mas Adcrno val mals ionge enquanto aponta uma possiblidade de ver uma vcrdade da ideologta (Beitzag zut Ideologienjehre. Schtiften \&. Soziologieche Sctuiten t, frankiturt: Suhromp, 1990 p. 472, mesmo que negativamerite, e ao ler o mundo concreto e particuiar como tecbmeno da ibcologio, o quo ndo pode ser pecsadc sem a conceito mandano, mas que o leva adiante. Asstm, o tema da tótciogia e fundamental na teccia de Adorno ao ponto de ter merocido do sua parte um artigo proocupado em considerd-to histcrich e sistematicamente, per cotsidetat que a comprecensto do conceito e da colsa que é a ideologha so b poeshel coquanto so comercende sua historia (p. 458), o que vem a signifles que a ideolojia consticui uma situapio tho abeangente capaz de acobertar e demonstrar suts prdprias cetratigies do instaraglo. Adomo, avancando em relspdo a Marx, sinda adapta sou concento a ums sociedade em que as clasecs faram tranaformada en maseas dortinadas por meice de comanicacto e por ums indistrla que o ê de becs cultathis.

27 Negatwo Dialektik. p. 62.

28 Negative Dialektik. p. 38. "Bewusstios gleichisam musste Bewusetsein sich verscriben in dio

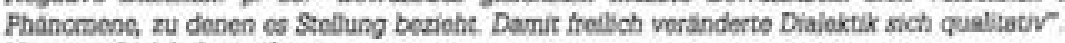
Negative Dialektik. D. 43. 
paradoxal, a sua possibilidiade de produzir emancipação ou servidão. Ou sefa, a filosotla tem tambem que avaliar o seu próprio instrumento para saber quals stio as condiçöes pragmáticas da sua mudança. So a partir da análise do estilo do ponsamento, do que ele significa e de como ele se expoe, e que o ensalo poderá surgir como o modo de tratar o objeto que tern em vista um ideal que ê em si ético: a primazia do objeto 30,31 diz respeito ao ideal nilo apenas gnosiológico, que pretende if alem da adaequation - ultrapassagem que $\hat{k}$, conforme Adorno, o significado próprio da dialética - mas, inclusive, ético, que reconhoce a dependência que todo sujeito tem da condiçio do objeto - que ele mesmo $\mathrm{e}^{\mathrm{x}}$ - sob todas as suas manifestaçbes e, assim, instaura um conhecimento enquanto açăo, nâo autoritário, pronto a ver a liberdade como algo a ser produzido para o outro como uma questalo de respeito ao seu direito. Por isso o conhecimento será uma forma de relação nascida numa tomada de posiçầo ética, ele sera o processo e o produto elaborados em uma posiçlo de respeito para com a coisa pensada porque ela, enquanto objeto - máscara do nầo idêntico ${ }^{34}$ - já nâo é mais vista como um simples instrumento manipulável ao bel prazer do sujeito.,55 Isto implica uma outra posiçăo do sujeito que se efetiva a partir de uma outra experiência com o objeto baseada naquela sua auto consciència como objeto. $O$ respeito em relação ao objeto será o caminho para a liberdade de sujeito e objeto, sendo assim que ela entrará no ptocesso do pensamento. A transformaçāo da fllosofla surgirá, entăo, a partir de uma transformaçăo da relaçăo entre sujeito e objeto que nāo deverd satisfazer-se $\mathrm{na}$ renúncia ao seu lugar em favor de uma relaçāo entre-sujeitos. Adorno permanecerá falando de sujeito (e do seu elemento objetivo) e objeto (e do seu elemento subjetivo) porque é ai que a utopia da reconcliaçảo tem seu lugat excelente nảo permutável por uma idéla de comunicação livte de violência, pois a comunicação Implica sempre violência enquanto ela despede de si o objeto como aquilo que nấo

10 Adorno, Theodor. Nogative Disloktik. Frankfurt (M): Sahrkamp, 1982. Scbte a "Primaria do Otjeto" (Vorrang des Objekss) hat um parligrado especisoo na Negueive Dlaiektsk, p. 184-183.

I Schwoppenhaluser, Hermann. Zur Dislektek der Subjektivitat bei Adorno. In Zaibschrit fur kritische Theorie. Luneburg: zu Kampen, 4/1997, p. 7, O auter deste artigo lembed a ressclo entre a mediaçlo entre sujeito e objeto na Elcoofia da identidade e da indisetenca do primeiro Schelling, apontando parn o futo de que "o objeto é o sujeito corponificado (inhorporierte Subjekt) e sujelto o objeto eepiritualizado (vergeistigte Objekt), elo é sinda, o nlo eu (Nicht-Jch), Naturoza do espirito vasivel o deus explicitas de Soctua Briugena - e Bu (teh), o espirito do Nlo- Bu invistivel - o deus implicltus. Natureza seria a concepplo do objetivo, o ea, a inteligbecis, a concepclo do subjetivo". Mass adiente die atrma que na flosotia tasdia de Scheliting apuroco uma despreporçlo critse sujeito e cbjeto, espirtto e natureza e ai o que pode set uma primacia do objeto em Adoemo: o Prius da natuzezs, seu "impeto" (Drangsh, sus "mania" (Suche, a "exietentia", o sem fundo (Mbgrand) anterioc ao fundamento (Grunch), as "espirite" (Ceist), à "muls alta essencialidade" (hochsten Wesentichea), assim esth em Adorno a primazia do cojeco antes do subetro e da subjerividade.

32 Nogutwo Dialektik. p. 16-17. Tal o que significa o Nome Dialctica para Adccno, gue co objetos nä́ serăo superados no conceito.

33 Sobre sujeito e Objeta. In Palswas e Sinsis. Modolas Criticoe 2. Trad Maria Helena Ruschel. Petropolas Voues, 1996 . p. 183.

Y Negative Dralcktik. p. 193.

35 Hh que se lembrar aqui a in Qulencia kerkegasediana sobec Adomo quando se pode pensar a relaçlo entro esto modo de conhecer pesstwo como sendo o mais probrio to conhecimento e a constderaçto de Keekegaard acerca da feminilidade (focminird genoris) do fendmeno. Ver O conceito de Irosis constantemente féfenido a Socrates. Trad. Alvato Luiz Moetenegro Valls. Petrópolis: Vozes, 1991. P. 23. 
pode falar. 0 objeto terá sua importáncia ao ser o representante da năo identidade que nå̃o pode ser eliminada sob pretexto algum, ele será o lugar de algo năo alcançado pela consciència $e$, neste sentido, nâo subsumivel ao principio da identidade. E será com a crueza desta impossibalidade, com este intenso năo idêntico ao qual a consciêncta deverá respeito - que o conhecimento deverá conviver quando, entăo, assumirả sua própria finitude, atitude fundamental na elaboraç̧̆o de sua perspectiva prática.

\section{Ética, critica e teoria do conbecimento}

A questaio da critica dará a forma com que se apresenta uma moral do pensamento na filosofia de Adorno capaz de set elaborada sob um conceito ético de filosotia que se vincula à idéia da interpretaçăo (Deutung) que aparece na liçăo "A atualidado da Filosofia". A questăo ê a transformaç̧o da teoria em príxis, o que implica fazer da interpretaçäo, que a filosotia e, um lugar de transtormação da sociedade, o que näo signnifica interpretar a realidade simplesmente, como Marx já criticava, mas fazer emergir o teor emancipatório e revolucionário da própria interpretaçåo e que define a própria necessidade de existéncia da filosofia. "A obsoles. céncia do conceito de filosatia, o momento de sua inatividade que é prectiso pensar também se se quer alcançar seu conceito, esta em conexáo com o fato de se ter convertido em falsa a possiblidade de uma vida justa. Mas se o motivo da vida justa, o pensamento tal como se deve vivé-la, desaparece, a filosofia também se acaba." "so Tais ypalavras de Adorno fazem ver a necessidade ética da junçâo entre teoria e prática.

Uma moral do pensamento que se impōe como impulso transcendental e, ao mesmo tempo, como necessidade histórica, nầo diz respeito ao que teria sido o mote subjetivo a partir do qual Adorno se viu, enquanto sujeito, envolvido com a filosoti, mas tem como base uma ética que subjaz ao sentido da critica, que se coloca all como seu impulso e que é o que levaria à construção do próprio pensamento. Entăo, por um lado, se ceveria falar de um elemento ético como impulso do pensar e como algo que lhe constitui propriamente e, mesmo assim, najo pensdla como fundamento. Ou seja, a teoria năo nasce de dentro da ética como sua consequêncis, e nem simplesmente o contrário: na construçăo de ambas há uma interconexão de impulsos éticos e teóricos o que não se deve pensar apenas no sentido de uma adjetivaçăo, mas de uma constituiçăo reciproca. Afirmar que um elemento ético está na base da formação da teoria não é afirmar que a fllosolia se transforma em ética, o que poderia levar à mudança do paradigma da consciência ou do linguístico rumo ao paradigma ético, $\odot$ que não teria sentido ou seria, de qualquer modo, altamente questionável. Trata-se muito mais de pensar o momento ético presente no processo do pensamento ou do conhecimento como elemento sern o qual é inviável a colocaçăo da pergunta pela verdade. Tal momento pode ser concebido na questão da primazia do objeto. $\mathrm{E}$ isto nấo diz respelto à uniăo platonica entre bem e verdade, pots a compreensăo de uma moral do pensamento apenas adquire sentido quando se considera o pensar como atitude que

* Terminologis Filositicas. . p. $100-101$. 
se constrơl também, inciusive, como politica - enquanto perspectiva prática estabelecida ao modo de um pano de fundo de uma teoria do conhecimento e da sociedade.

Ao afirmar que "a autocritica da razlo é sua majs autêntica moral"zo Adorno está declarando a base de uma moral ${ }^{\text {* }}$ do pensamento, o que nllo significa uma moral a partir da qual se deve pensar - e neste sentido que existam regras e hábitos considerados corretos a partir dos quais se elabora o pensamento ou a teoria, o que, de certo modo, os aprisionarla. Uma moral do pensamento nĩo deve signifcar que a teoria deva viver sob o jugo de uma coaçlo moral (Gowissenszwang). ${ }^{\text {to }}$ Ou que dentro dela se possam simplesmente transformar categorias episternológicas em morais, quando entāo a filosofia de Adorno cairia justamente na postura que ela busca abolir - quando ela considerasse, com a major parte do pensamento, escándalo a idéla de uma filosotia sem base $e^{60}$ qual, entretanto, por força da critica, ela assume, năo como provocaçăo, mas como modo ético de se colocar no luggar social destinado ao pensar. A questâo seria reverter esta separaçăo ideológica entre o gnosiologico e o ético, entre o conhecimento e a sociedade, avaliando o fundo social do conhecimento e da forma do pensar.

A ética, assim, nẫo pode ser o fundamento da filosofia ou do pensamento porque se deve compreender a constituiçäo reciproca entre eles e, neste caso, a relaçāo entre teoria e prática. Mas há uma queståo anterior posta no próprio ato do conhecer enquanto ele é compreendido como "postura" da consciéncia que permite conhecer, sem fazer do conhecimento uma projeçáo. É preciso pensar-se, neste caso, que a pergunta pela anterioridade de um ou outro, $\theta$, ela mesma, imposta pela consciéncja que deseja, mals do que conhecer, obter segurança, a qual, para ela, define a necessidade de um fundamento. Adorno nắo quer colocar a ética como base de sua filosofia - seria mesmo apressado querer imputar-lhe tal estratéggia, embora seja ao fim e ao cabo, tambérn esta a questấo que está em jogo porque na corrente da sua histórla a filosofia inteira procura um primum e constrói-se nesta possibilidade e a filosofia que se esquivasse dessa espécle de busca delxaria de ser considerada flosofia propriamente. Adorno quererá pensar, neste sentido, o sem-fundamento, pois uma fllosofia que se auto critica quer ser fllosofia última e năo prima fllosofia, ${ }^{41}$ aquela que pretende eliminar a si mesma - num mundo ideal ela năo será necessária - já que percebeu o parentesco entre o primum e a auto conservaçăo năo só da teoria propriamente, mas de tudo que dela decorre, $\mathrm{B}$ isso que faz com que toda filosolia dependa de sua própria história que, por sua vez, traça o motivo a partir do qual a filosofia mesma pode existir: a culpe, experimentada por Adorno quando da perseguiçāo nazista, de se estar vivo por

37 Minima Moralio p. 163.

It Seria necessirio distinguir mocal e ética em Adomo. A segunda sparece como algo mais abstrato

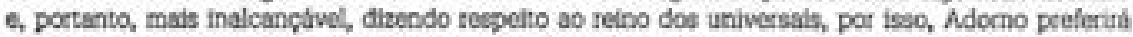
Lsar conatinternente o termo moral, como a açio individual, respoctiva ao reino do particular, unt. co lugar conde questbes morais ainda podem ter validade. Falar do uma moxal é, de certo modo, excluir a etica ou coloch-la no campo do impondertivel, do utiógico, do ideal com o qual et preciso tolacicnar-pe, mas com uma confiança testrita que impeça que ele se transformo on engodo.

39 Negative Dialektik. D. 42.

4. Negative Dialektik. p. 45 .

41 Zur Motaknitik der Brkenatnisthoorie. p. 47 
acaso e que jeva a uma noçä̀ de solidariedade sob a qual a filosotia é obrigada a rever sua posiçầ: "o sofrimento perpetuado tem tanto direito a expressăo como o torturado a gritar; por isso taivez tenha se tornado falso dizer que após Auschwitz. nenhum poema possa mais ser escrito. Porém não é falsa a questão cultural menot de se após Auschwitz ainda se pode viver, se seria de todo permitido a quem casualmente escapou e legalmente tivesse que ser assassinado". ${ }^{2}$ A questlo do sujeito particular e sua conexảo com as demais vidas e o absurdo no qual todos estão envolvidos define o sentido de uma dialética negativa.

Assim, falar de uma moral do pensamento teria mals a ver com o que Nietzsche em Para além de Bem $\in \mathrm{Mal}$ chama "honostidade", aquilo que, para ele, falta aos tilbsolos impedindo-os de chegar a verdade. Honestidade seria, transportando tal conceito ao pensamento de Adorno, năo apenas uma intenção do sujeito envolvido, mas um comportamento da consciência face ás exigências da teoria e da prática, algo que viesse a dar orientaçio ao pensamento enquanto o constituisse como comprometimento com a verdade. Algo que ultrapassa a lógica, e que ao mesmo tempo poe a estrutura formal e conteudistica - a filosofia para Adorno é uma busca pelo conteudo ${ }^{H}$ - do pensar, que o constitul enquanto tal, $e$, neste caso, impbe o amálgama entre ética, critica e auto critica. Neste ponto é melhor afirmar que há uma alteraçăo qualitativa da logica interna ao pensar, do conceito, da forma da escrita e, portanto, da apresentação da filosofia. Realizar um pensamento honesto seria ter em conta os limites da filosofia e a necessidade de situar seu potencial emancipatório no mundo da vida concteta.

Uma moral do pensamento implica sua auto-análise. Colrio se o pensamento que năo pensa a si mesmo näo garantisse sua própria validade e verdade ou anulasse as condições para isso na medida em que se exclui daquilo mesmo sobre o que fala. Isto colocarla em cena a hipótese de que a verdade depende do modo como ela fol declarada e que este modo tem que ser filtrado pela análise de si mesno. Quem exige a verdade tem que falar a verdade que apenas nasce na critica e na autocritica - critica sem auto critica é justamente o pressuposto de uma falsa moral. B́ esta junçào que está em jogo, pois em que sentido ela pode ser

42 Negucive Dlalektik. D. 365. "Das perennierende Leiden hat sovicl Recht auf Ausdruck wio dor Gemerterte zu brullen; darum mag falgch gewesen sein, nach Auschwiez liesse kein Gedicht meht sich schretben. Nicht falsch aber ist die minder kulturelle Frage ob nach Auschwitz noch sich be.

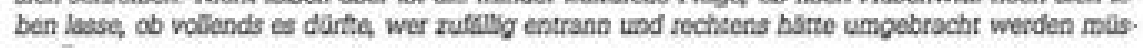
sen,"

4 Nietzsche, $Z$. Jenseits von Gut und BCse. Werko in diet Bunden. B 2. Menchen: Kart Hanser, 1973. p. 570-571. Nietzsche afirma serem os fichofos todca defensores dos proprios preconoetios e, pcrtanto de uma moral coe tem como base a lavenclo do verdades, que olo faz pesear por deceober: to. A atisude legitims do quem nâo cues ser simplesmente um tal delensor seria, como indica o ptcosdimento genealógico de Nietzeche, buecar donde veriam sabdo as verdades, o que se ecocode por tris delas. Niato sesidiria uma horestidode do espirito como o coctrária da sua poópria auto. conservaglo, o que significa nầ compactuas con uma moral pro-estabejecida es nes mesmo, pura e simplesmente, tunder uma nova. A questlo da moral cra Adorno se pöe como consequetencia des conquirtas nietascheanas neste ambito, da qual devern talmente ser tributáias todis as tocrias pooteriores a cie, como noca Ulich Kohlmann (Diajoktik dor Moral. Op. et. D. 13). A relaçlo tributirta para com Netasche poe parte de Adorno é percebida tambem, embora noutro vils, pot Wischike, Mirko em Die Geburt der Bthik. Op. eit. p. 49.94.

Nogative Dialektik. p. 66. 
sustentada, se do ponto de vista lógico ela năo tem consistência? A questăo é a auto critica da posiçắo subjetiva da teoria que ple em ceña a sua capaçidade ou nâo de fulgar, avaliar, exercitar-se como pensamento critico. Isto quer significar que quem năo corresponde às exigências do seu próprio pensar $e$ agir está sendo falso. Neste caso, a objetividade dependeria de uma subjetividade correta? Mas isto não seria uma falácia? Como pode uma teoria ser ética se isto se płe adjetivamente? A queståo é, inclusive, entender que é possivel ser falso e verdadeiro do ponto de vista da açấ moral e do conhecimento e que, se categorias gnosiologglcas săo cabivieis no nivel da açăo motal, categcrias éticas ou morais tambem podem ter sua validade no campo gnosiológico, o que năo significa apenas um intercâmbio de categorias ou a reediçăo do velho constructo platônico. A verdade enquanto condiçăo - vale para uma ou outra esfera. Cabe ver como a teoria de Adorno parece promover este entrelaçamento - é isso que se mostra na afirmaçăo de que o conceito "está fundido com o năo verdadeiro, com o principio opressor, e isto diminui sua dignidade de critica do conhecimento" 45 - e qual seria a importáncia disso para a filosotia ${ }^{\text {\& }}$

A remessa mútua entre ética e teoria do conhecimento é o que ele insinua, tamberm, no último parágrafo đe Minima Moralia ao falar do sentido da filosofia em face do desespero como "a tentativa de considerar todas as colsas tais como elas se apresentariam a partir de si mesmas do ponto de vista da redençâo"," enquanto momento e lugar onde as contradiçōes năo existiriam, oposiçăo à situaçăo falsa para a qual a dialética negativa quer ser uma ontologia. Se vige a falsidede, o império da ideologia, a redenção tem o objetivo de orientação de uma práxis que visa eliminar a falsidade de uma vida năo mais boa, uma vida danificada como reza o subtitulo das Minima Moralia. Nesta medida a redenção seria a verdade exposta na sua face teórica e prática. Af residiria a tarefa da tilosofia que detine o alcance prático do pensamento e que só é pcssivel na consciência que tem o pensamento de sou próprio condicionamento, quando, entăo, ele mesmo e capaz de compreender sua limitaçlo e a exiģência que nasce dela," ou seja, o pensar nấo

45 Nogative Dialektik, p. 57.

4. Nlo teria sentido ca, pelo mence ndo seris necessáno, a partir disso, eequematizar de um lado uma tecria do cunbecimento e, doutro, uma etica do ponto de vista de fdorno c, assim, estabeleor um confrceto entre o rooulitado des daus construpdes - principalmonte porque Adorno nunca escrevea explicitamente sober as questibes que pot oca sdo intertogadas. No entanto, a literatura sobre uma ética poesivel a partir da fllosolia de Adorno cresce no coeteoto dos seus estudos. Ha o livio de Rlobert Schurz Fthik nach Adorno(1983), o de H. Schweppenhbuser Bthik nach Auschwitz (1993), o de Mirko Wischke Kritk der Ethik des Gehorsams;1993) e Die Geburt der Bthik (1995) e Dislektik der Moral de U. Kohimacn (1997). O segundo, o quarto e o quinto destes estudos citam as Lęles proberidas por Adorno no semestre de $195 \delta / 57$ na Universidode de Frankfurt, intituladas Probleme der Moralphiloscplive e que estáo no Theodor W. Adorno-Arguiv, sendo, portanto, estu. dos, que se podertam considerar, bastante completce sobec o tems o que thm, guardadas as pecu. liaridades de cada um, a pretenshio geral de estabelecer relaçes entre as questbes morais em

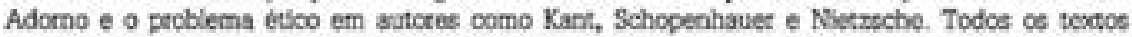
siatematizam a quert bo da maral em Adorno selacionando-a o sab histórin anterior.

क7 Minime Moralie. D. 353 . "Philosophis, wie sie in Angesicht der Verzweilfung oinzig noch zu verantworten ist, walre der Versuch, alle Dinge so zu betractiten, wie sie vom Standpunkt der ErJdsung sus sich darstallen". Trad. p. 153

48 Minime Moraba. p. 334 . Trad. p. 216. 
deve ao perceber seu limite, ceder de sua tarefa que è justamente transpô-lo. A tarefa do pensamento para além da possibalidade da própria redençăo, no ato de comprcender a verdade que the está aquém, a qual a redençấo deve servir de medida. Nisto consistiria um traço pessimista do pensamento: que ele deve realzar sua tarefa como algo mais fundamental do que a propria esperança que o move, que apesar dela, ele deve agir, enquanto se exerce, em funçăo da idéta de sua impossibilidade para além da limitação do mundo; ela năo pode dizer respeito a um estado de perfeiçalo externo. Pois, mesmo necessária ela é, enquanto absoluto, apenas quimera. Por isso, trata-se da esperança sem esperança que se faz. consciente transmutando-se em materialismo. Por isso o pensamento espera a redençắo, mas sabe que ela é impossivel. Na conscléncia desta impossibilidade do caráter irrealizdivel da utopia - é cue ele se toma critico, porque na desesperança é que a esperança adquire sentido para além da confiança pura e simples em tempos melhores. Desta descrença é que nasce a necessidade do trabelho prático para um mundo melhor na perspectiva das condiçós materiais da vida. Bis posta a tarefa, o "que fazer" da filosofia que deverá ajudar a definir o sentido também desta esperança para além da pura teologia.

Uma moral do pensamento coloca a intima conexāo entre a teoria $\theta$ a prática e a inevitabilidade da sua cisăo. Por isso tem sentido faiat de uma "tarefa (Aufgabe) da filosofia", na qual a força do sujeito (Kraft des Subjekts) que quebra a subjetividade constitutiva (konstitutiver Subjektivitatt) é imprescindivel. plicidade desta tarefa depende disto, do fortalecimento do sufeito contra o sujeito enrijecido, petrificado, aquele que, morto, mata o objeto tornando-se incapaz de relacionar-se com ele enquanto poténcia emancipatória. Neste sentido é que a teoria seria uma forma de práxis que, de um lado, transforma qualitativamente a subjetividade e a razâo através de uma alteraçăo do conceito de objeto que nada mais é do que o ato de percebe-lo para além dos ditames da subjetividade fechada em si. Esta forma de práxis será, portanto, o lugar da esperança ${ }^{50}$ para o mundo, 0 que faz com que a teoria reforce seu sentido. A tarefa da flosofia colocar-se-á muito objetivamente sob a forma da tarefa da teoria critica: lutar contra a recaida na barbáries: exposta tambèm ao nivel de uma carta forma de teoria que compactua com o status quo injusto da sociedade na qual a barbérie é perpetuada. Isto mostrará que em Adorno teoria e práxis estáo de uma lado muito unidas (observando as mesmas regras sociais, os mesmos condicionamentos e determinando-se reciprocamente) e, de outro, muito separades (a prática náo realiza o ideal da teoria). Bstăo unidas no sentido do ideal e separadas no nivel do real. A tarefa da teoria será, inciusive, trabainar esta questão, tomando o ideal real e năo subsumindo o mundo da vida concteta sob telas conceituais.

A transformaçlo da fllosotio, portanto, diré respeito a esta recolocaçấo do ponto de vista ético no seu interior - que só é possivel na compreensấ do con-

\footnotetext{
45 Negative Dialaktik. D. 10. Tal serta a tasefa que Adorno tama explicitumente para si meamo como sujetto.

50 Habormas afirma que Adorno a abandonoa. Op. cit. p. 499 (nota).

51 Negative Dialektik. p. 205.
} 
ceito de "experiência flosofica"siz que é a experiência da morte $e^{53}$ - ea reavaliaçlo do sentido que a flosofia adquire após um tal acontecimento. E quando se torna necessário voltar ao problema da perda como significante da dialética e da filosofia, considerando a questăo que se pōe como estigma da concepçāo de histótia construida na dialética neggativa a qual reza que a injustiça aos mortos é irrepará-

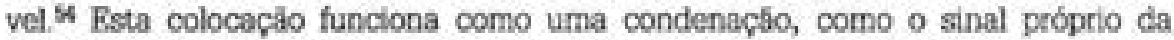
danaçáo por seu próprio conceito irreversivel e a tarefa da dialetica incapaz de reverter tal situaçäo é apontar para a verdade contida neia e o potencial redentor que ela lança ao futuro.

A dialética como perda (forma precipua da morto) - uma dialética invertida, nascida na contracorrente da hegeliana, da sua leitura avessa, das marcas por ela deixadas (condição que Adomo mesmo abre ao talar da perspectiva da perda que a filosotia de Hogel esboça, naquele caso, da perda da obrigatoriedade da individualidade como força para alcançar o universal, 55 e que mostra a leitura a partir do que Hegel deixou como resto, como resquício inconsciente, definindo aquilo que nấo pode ser suprassumido pela dialética) - será o modo como esta filosofla se expressa a partir do que foi perdido e năo pode ser integrado. Bla se faz dos restos da fllosotia hegelana, como a su necessária contrapartida histórica, como seu espelho onde as consequências de seu intento se fazem evidentes. Tal perda dirá respeito ao esquecimento dentro da fllosofia possibilitado pela própria instrumentalizaçlo da razăo filasófica totalmente voltada para o progresso cego de si mesma e do mundo que ela ajuda a produzir. Nesta perspectiva, os elementos e a propria história da fllosofia podem ser vistos a pertir do que năo sâo ou do que debcaram de ser, do que nāo puderam ser, do que recalcaram para poderem ser (a subjetividade $e^{56}$ deixa um inconsciente e se instrumentaliza, o conceito deixa um objeto, a teoria e a razăo delxam a natureza, o progresso deixa a decadência), quando, entalo, ser e não-ser adquirem o mesmo peso do ponto de vista histórico o que fustifica, por sua vez, uma forma de compreensāo da contradição e do sentido da dialetica. Isto implica pensar o próprio conceito de história da fllosofia como resto, marca, cicatriz que deve ser analisada como um negativo.

52 Segundo Adocno é isto que ele quer fustilfcar na introduçbo de sas Nogative Dialektik. No predacia. p. 10 .

53. Philoeophische Terminclogie. D. 101.

54 Nogotivo Dialokitik. p. 378.

5 Negative Dialektik. p. 344.

56 A perda, corso forma de estruturaçlo da dialetica, serd o ensejo da etica, posto que fonte da critica 8 ser tealizads pelo sujeito. Mas se a subjetividsde é tambem o que se perde, a questlo é retraç. 12. Na Dialitica do Declarecimento a condiglo da peeda 6 expecesta sob a forma do processo de formeglo da subjetividade e no reculcamento de sua histbria, bo fasto de que cs individucs odeiam o passado porque este farta lembrar a ruina da vida que, para Adorno, deccere tambem deste recalque (Dislektek der Atufkainung. D. 225-208). Por isso a "rememcraçio de natureza no sujeito" IDV-

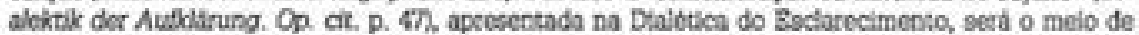
recuperar a subjetividade, nifo na totalidade - 0 que 6 impossivel na medida em que ela mesma ê detinida pelo que cla perdeu, mas como modo peodiativo de penear o que se fol e as conecqulencias de sue inabarcabulidade e de suas cicutrizes. $A$ ernancipaçio do sujeito da cpressibo de suto con-

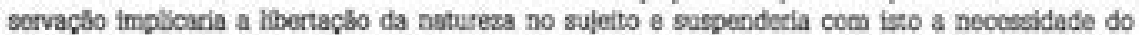
daminio do sujetto sobre a tatureza (todke, Martin. Anmerhungen zu einer "Logik des Zerfalls". Adorno-Beckett. Frankfurt (M): Suhrkamp, 1981. p. 433), porque ele mesmo, de certo modo, coeno que se reconciliaria com eata parte de aua verdade. Diato nasce uma nova coensideraglo sobce a moral. 
B assim que o que fol perdido è capaz de traçar os passos de um "dever-ser", ou melhor, do que nấo deveria ser, do que năo deveria ter sido e, até mesmo, do que deverá ter sido. Se não há, considerando o teor do pessimismo da teoria critr$\mathrm{ca}$, redençáo para o passado, o presente, entretanto, precisa ser salvo, apesar da disposiçào das dificuldades. Toda moral, enquanto tem em vista esta dependência do que năo pode ser reparado, assim como toda teoria do conhecimento, é a elaboraçăo de um luto: 0 luto "toma-se a ferida da civilizaçăo, a sentimentalidade associal que denuncia que ainda năo se alcançou totalmente um comprometimento da humanidade com o reino dos fins".57 Nesta lembrança - que implica a compreensäo de uma questảo moral a ela imanente - reside também a chance da filosofia como práxis. Porque a morte se faz lembrar sempre nas formas presentes e atuais da barbárie, sendo o que náo deveria ser, é que há sentido em se pensar em filosofia.58

A transformaçào da fllosofia dentro do projeto de uma "práxis transformadora" que precisa iniclar com a teorla se dé, entlo, nâo no sentido apenas de uma teoria estética (como seria comum de se pensar no contexto da fllosofia de Adomo), que se coloca como arte ou que refete sobre a arte e procura um espaço para uma sua autonomia radical - e que acabaria por Jevar a ética ao contexto de uma impossibillidade nílilista -, mas, antes disso, como ética, queståo anterior, do ponto de vista da lógrica da teoria, a queståo estética e que, em certo sentido, a engloba. A grande contradiçáo a set enfrentada e que acaba por dar um sentido muito particular ao pensamento de Adorno, diz respeito ao fato de que este elemento ou esta circunståncia ética dentro da qual surge a teoria depende de um tópos estético. Tratar-se-fa, portanto, de uma teorla que se constról no entrelaçamento de um substrato ético e estético numa uniâo sob um aspecto inseparável, ${ }^{5}$ o que e dito aqui na tentativa de afirmar o sentido segundo o qual as experièncias etica e estetica se constituem no mesmo momento: por isso será central pensar o momento do horror, do estranho que é tipico na experiência estética e que caracteriza tam-

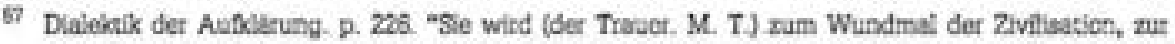
stociden Sentimentaltait, die veerlit, dass es immer noch micht ganz gelungen ist, die Kenocher eufls Reckch der Zwecke au vereidigen."

se Bm Terminologia Filosoffca II, Adoeno expóe a sdels da fijosctia enquanto experiencia da morte. Poder-se-ia dicer que am A Aruabdade da Nlacoba, na Dialtica Nogutiva e em Minima Maralia cle trabalha a condipdo finits de próprio discures fllosobco de um modo, apesar de tudo, considetaveimeete stotematica. A tematica de morte - que e a mesma da perda com a diferença de que ao se falar em perda se abre umi perspectiva dialética a morte enquanto ela nlo se fax de modo tlo abscluto guanto na morte, pols a solia do perdido femplica que ele ainda existe, permaneco presente ha sua susbenctia, paradcoco que a filoestia de ve tentar compteender como condiclo de sua propria verdado - da pedpria Elcoolia cstd presento, Do minimo de um modo sabjaconte, em toda a

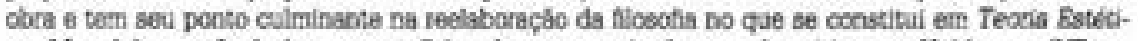
ca. Mas Adorro alo fard uma metafisica da mocte, etifude que ele critica cm Heldegger (ND. D. 361-3623, enquanto busca de sentido, porque a morte è, justamente o que nào sen sentido, o que Dlo deveria excate.

59. Martin Ladke (op. at. p. 43) considera que a estetica 6 o ponto cuntral de teoria de Adorno e, dectro dela o belo naturai é a quest\$o fundamental. Mas o próprio belo natura' acaba trazendo d tona uma questlo ética que nilo se reduz al estetica e que mesmo é colocada all pot questîes éticae. Nes Ludhe afirma $(0,4)$ que a tocrla de sociodode de Adomo, que e code se pode levartar o problema mocal, se rebogia na estética na considersgio do belo nasural como o nío idintico. 
bém a experiéncia ética em Adorno. Neste caso, toda a estética é marcada por um momento ético: a própria questẫo da autonomia da arte, por exemplo, neste sentido, diz respeito à reviravolta ética da estética contra a ética tradicional e um contexto social injusto e bärbaro que a ética nâo é capaz de eliminar. No entanto, por si só, esta afirmaçào năo seria qualquer força para substituit a estética pela ética. Mais dialeticamente, contudo, há que se perceber o intercałmbìio e a conexăo entre estética e ética, sem buscar nelas uma hierarquia indevida, mesmo porque a ética exige a expressắo do verdadeiro refuglado na arte.

A filosofia de Adorno voltar-se-á para eate espaço abandonado, buscando nele a verdade perdida na tentativa de abrir um outro caminho para 0 conhecimento preso à neurose do universal, à paranóia sobre a qual Adorno fala em sua Dialética do Esclarecimento. ${ }^{\infty}$ Entâo, flosofia será algo prático e material, uma práxis transformadora, que se voita ao particular. Por isso, na fllosotia de Adorno, teorla do conhecimento e teorla da sociedade serăo dots lados da mesma moeda, ${ }^{61}$ nâo nos termos de que a dialética possa ser uma sociologia do saber, mas porque "o acesso das categorias sociais se faz através da decifraçễo do conteúdo de verdade das filosóficas". "2 A formaçăo da teotia e 08 processos que definem as condiçōes da socledade sắo o mesmo.

Isto implica pensar que a teoria enquanto critica é materialista também no sentido de "melhorar a sorte da comunidade" cons cono afirma Horkheimer - quando ela entäo se torna teoria qua prática - e de ultrapassar o sentido pejorativo daquilo que a filosofia tradicional chamou metabase $e^{65}$ mostrando sua verdade: quando o pensar quer ser açlo para além de um ato de fala sublimado em si mesmo: tal açăo quer ser transformaçào das condiçbes concretas da vida. O materialismo de fliosofia adorniana aparece na recuperaçróo do objeto tanto no aspecto gnosiológico quanto sociológico o que dá o sentido do que seja a práxis no seu pensamento.

A primazia do objeto elabora-se tambem como critica "porque através dela é revelado o carater de aparência da troca que é refletido como fenómeno da coisilicaçao. Através desta reflexalo, porém, deve ser apresentado também o caráter verdadeiro da primazia do objeto que se diferencia da objetividade da aparéncia da sociedade de troca e, ao mesmo tempo, tem em vista um sujeito e uma sociedade livres". ${ }^{\circ} \mathrm{Na}$ relaçâo de troca, e também na de uso, a partir da qual o objeto è visto, ele deixa de ser algo assustador enquanto forma de apresentaçäo do que

60 Dialektik der Aufklsing. Frankluru,M): Pucher, 1969. p. 206-207.

61 Sobre Suletto e Objeta. In Palavras e Sinais. Op cit. p. 189

62 Nogative Dialoktik. p. 198. "In gosellschaftiche Kotegorien ist philosophisech uberougehen allein durch Dechittierung dos Waheheitsgehalts der philosoghischen."

60 Horkheimer, Max. Materialismo e Mctal. In Teoria Critica I. S5o Paulo: Pespectiva/EDUSP: 1990. D. 79

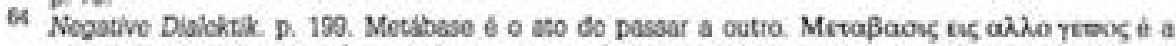
expresslo que se tounou famcsa desde que usada por Arietotelas no De Caelo, A 1, 288 b 1, que paseou depcis a tetorica subecquente, fndicando a passagem de um argamento ao outro e, portasto, tamberm a pessagens de un plano a cutso de raciocinio. Ver Reale, G. Historia do Flosofia anciga. V. 5 .SP: Loyols, 1985.

6 Tong, Guomu. Op, cit. p. 11. 
nåo se deixa colsificar. ${ }^{60}$ Na relaçăo de troca o objeto $\&$ uma coisa. Fora desta relaçáo ele năo pode ser aprisionado tornando-se perigoso para o sujeito petrificado.

Mas somente através da consciência de um tal estado - a consciência da condiçáo da subjetividade esmagadora que é anteriọr à sua exdstência - é que o sujeito poderia vir a ser recuperado. $\hat{B}$ a isto que leva a filosolia de Adorno, recuperar o sujeito a partir da recuperaçāo do objeto. Objetividade é, neste caso, algo que deve ser revisto tanto quanto a subjetividade. No espaço do conhecimento, a primazia do objeto alerta, portanto, para algo que deve ser recuperado sob pena da aniquilaçăo do próprio sujeito. Nâo existe sujeito sem objeto, o próprio sujeito é objeto, tal é a tese de Adorno, e mesmo a teoria que mais preze a ideja de uma pureza do pensamento - atributo do sujeito - jamais podera livrar-se do pensado, o "algo" como "residuo metalógico" que aparece na Dialética negativa" e que é o próprio representante do objeto.

Quando a primazia do objeto é sustentada, Adorno abre espaço para um elemento fisico - porque "todo o espiritual é impulso tisico modificado" no pensar, mostrando o sentido próprio da dialética enquanto dor elevada a con. ceito. ${ }^{\text {to }}$ A dialética materialista $\theta$ a petrificaçăo da dor, em outras palavras, sotrimento tornado concaito que a dialética à base da identidade tenta ocultar. ${ }^{n}$ Solrmento ou dor sấ, também conceitos que representam o que resta, após tudo o que fol perdido e não pode ser recuperado. ${ }^{7}$ No entanto, representarn aquilo que 0 conceito năo consegue subsumir, sendo a impureza maior e năo sublimável presente na formaçăo do conceito.

Af, adquire maior clarificaçâo a queståo sobre a aniquilação da filosolia: em um certo sentido, ela é, desde o momento em que se institui como forma de conhecimento representacional, uma forma de sofrimento, como que um lamento, ou a sua manifestaça, por sobre tudo o que a fllosofia deve recalcar ou abandonar para poder instituir-se. Isto nâo quer dizer que o trabalho fllosótico seja dificil, complexo e, portanto doloroso, mas que ele nasce de uma experiência da situaçăo de desdouro do sujeito em meio a sociedade. Há nisto algo da Weltschmerz tomántica. Noutro sentido, o coccaito é em si mesmo sofrimento nascido do abandono inevitável do real que teria ocorrido, em funçăo da dificuldade fornecida pelo proprio real no que se refere ao seu conhecimento e manejo pelo pensar e, neste caso, é como se o pensamento sofresse enquanto lembrasse do que ele deixou

66 -Marx ja manibesta a diferenca entre a primaxia do cbjeto unquanto algo produzido criticamento $\mathrm{C}$ sua caricatura no exdstento, sas deformaço atravis do cartiter da mercodoria". In Marx bereits sprich die Different zwischen dem Vortang des Objekts als einem kritischer Herzastelenden und setner Fratze im Bestehenden, ectner Verzerrupg darch don Warencharaices eich aus". Negative Dialoktk. p. 190.

67 Negative Disicktik. p. 139

68 Negutive Diabktik. p. 20e "Alis Geistige iat modifiziort leibhafter Impuls.."

6 Negutivo Dlaicktik. p. 18

70 Negutive Dialaktik. p. 200.

71 S isto que demanstra o traço pessimista da tecria de Adorno que aparece também em Heckheimer em Macerialismo e Metafisica. in Teoria Critica L. Op. cit. p. 43. 
para trás, o que se efetivou consciente e fnconscientemente. Neste sentido o próprio pensar, seja ele critico ou nd̃o, institul-se como sofrimento - acriticamente, para poder auto conservar-se, ele exercita-se no sacrificio do sentimento e da relaçăo possivel com o que ele tẫo é capaz de entender, posteriormente eie se torna critico em funçăo da consclẻncia de tal sofrimento e sofre por perceber a injustiça que ele ajudou a produzir por açăo ou omisstio.

Através da tomada de conscléncia por parte do pensamento de seu momento somático, de uma dor que agora deve ser extinta na prática é que materialismo e critica convergem, segundo Adorno, com a práxis transformadora da sociedade. ${ }^{n}$ A dor, é preciso aqui pensar-se nestes termos, apenas pode ser sublimada quando o pensar transtormar-se em açâ. ${ }^{n}$

Neste meio, poder-se-fa afirmar que o objeso é o representante de uma tal perda, ele é aquilo que nào pode ser digerido pelo pensar e adquire, af, um caráter metafisico - caráter, no entanto, negativo do materialismo, uma metafistca que restringe-se à imanência e nấo espera a transcendéncia num mundo além do mundo - pois a perda que ele representa é a forma que ele encontra para trazer á presença o sofrimento dentro do conhecimento - o que, todavia, so se dá historicamente.

Se o objeto pode ser recuperado - e é isso que se procura - no nível do conhecimento, o mesmo não ocorre com o que foi morto dentro da sociedade. Entâo, e ai que o pensamento, para Adorno, deve se unir à dor ${ }^{74}-0$ que evidencia a posiçăo moral do pensamento nâo apenas no nivel de uma intençăo, mas como algo que o determina historicamente. Pot isso a forma como a filosofia de Adorno se expōe serd determinada pela dor. Bxpressto e sofrimento farăo uma constelaçào norteadora da liberdade do pensamento. $O$ solrimento será a sua eloquèença,7 momento em que a frracionalidade aparece no pensar sob a forma da expressato que não deve abandonar o rigor. ${ }^{7}$ A filosolia trabalhará com uma forma expressiva recuperando um elemento de sensibilìiade para além da separaçâo formalizada em Kant entre a sua forma $e$ a do entendimento. A recuperaçlo da sensibilidade por parte da teoria tem a ver com o conceito ético de fliosofta que quer fazer fustiça tambem a si mesma, assim como aos conteidos e formas do saber negligenciados ou solapados pelo império da racionalidade instrumetal.

Por isso, se uma utopla do conhecimento 77 - que pretende chegar ao năo conceitual atravís do conceitual - aparece como próxima da realizaçâo, o mesmo nâo se dả com a utopla da socledade, onde certas perdas săo inexoráveis. Ai o conhecimento na forma da dialética negativa, solidariza-se com a sociedade na forma das vidas e experiências perdidas. Entảo, a perda que diz respeito à experiência eleva-se à categoria, a conceito. Se a sociedade está dentro do pensamento ${ }^{\pi}$ en-

\footnotetext{
Nogutivo Dialeitik. p. 2003.

3 Nocss marginats sobre Tooria e Prixis. p. 204.

74 Nogstive Dislaktik. p. 18. A dot o pensamento deve mestno se submoter, so sujeitar thr muss Erkenntris sich figen. J).

75 Nogative Dialektik. p. 29.

76 Nogutive Dialektik. p. 29. Trata-se aqui de Auedruck e Stringenz.

$n$ Negstive Dialikicik. p. 21

t8 Sobre Sujeito e Objeta. p. 189.
} 
quanto é seu material, o próprio pensar terạ em conta que a realizaçăo da utopia da reconciliaçáo apenas no seu ámbito será pura flusâo ou engodo. Mas è a utopia que orienta o pensamento filosofico. Neste contexto é que se poderá dizer que a fliosofia é a experiencia do sofrimento compartilhado com o mundo real. Pensar é experiência e ndio sem dot considerando-se as condiçbes do mundo, mas é, por outro lado, o desejo de transcender a dor, por isso ele deve ser estimulado e orientado pela utopla. Bis o momento em que a metafisica adquire sentido como materialismo.

Se o pensar é algo, ao fundo, material, que carrega em sí algo "năo puramente cognitivo", ${ }^{\prime \prime}$ e nảo é, portanto, pura abstração, é isto que a razdlo deveria recuperar para poder continuar no seu caminho. Isto significa que a consciência e a matéria numa oposiçấo nấo dialética năo podem lutar por um lugar absoluto que elimine sua oposição, o contrário seria uma regressăo de parte à parte. ${ }^{20}$ Se ela nāo pode recuperar o que se perdeu, pois o impossivel, deve, ao menos, tentar trazet para si a memória do solrimento e o próprio sofrimento presente que ela tenta esconder. Por isso, ao se falar em dialética em Adorno, não se pode apenas permanecer na idéla de uma luta entre opostos em busca de sintese, mas é preciso compreendê-la como a compreensāo e a lucidez nascida no encontro com o sofrimento (fundamentalmente fisico) do qual a dialética nogativa é a forma conceitual. Por isso, a síntese soa no seu contexto como algo enganoso. Neste sentido, ela é uma dialética tanática, porque ela desejaria, do ponto de vista da utopia, nlio existir ${ }^{61}$ e trabalha - na perspectiva do materialismo $0^{2 a}$ - para isso, mesmo tendo a consciência de que se trata de uma plena utopia pela qual ela opta como forma de existir eticamente - a dialetica negativa ê uma forma de solidariedade com o que sofre enquanto ela mesma $e$ solrimento. Por isso è necessário reavaliar o sentido da teoria, para que a utopia do conhecimento se torne prática. Aí ética e conhecimento selo solidários. Els a forma inicial de transtormaçâo da fllosofia: o amalgamar de ética e comportamento da consciéncla na forma da critica.

A consideraçâo da idésa da perda como organizadora da dialética negativa pretende por em evidència o lado prático de elementos té́ricos. A "perda" é, neste sentido, uma "idéia-prática", na medida em que, ao ser posta, traz à tona um conteudo que é do seu desejo salvar. Ela é uma ideia que se deseja redentora enquanto, pelo fato de sugerir-se como tal, traz a presença e problematiza o que havia sido perdido. Tem em si, portanto, um caráter mnemónico, retroativo, que faz voltar o passado na sua ausência. Ela é prática porque ao ser posta faz tarnbém aparecer um conteúdo emancipatório negativo na medida de sua impotência rela-

70 Nogotivo Dialoktik. p. 194.

10 Negative Dialektik. p. 205.

81 A utopia da Rectnclisglo (Versobnung) impica o fato de que a Dialbeica um dia deveria ndo ser mais necessinia, posto que ela edste pels dar çoe deve ser etirnirnede. B isto que Adorno quer di-

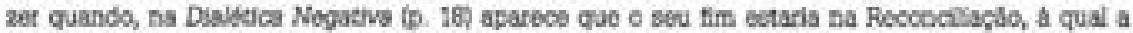
dialletica serve. A dialetsca, enquanto "contologia da situagclo falea" OND. p. 22), torna-se degneces-

Nogucive Dialoktik. p. 207. 
tiva ao que passou, mas positivo quando aponta para o que precisa ocorter em termos de redenção. Está implicito zisto o fato de que ela só poderà ser lembrança do passado que o invoca como um vazio e que jamais poderá ser a sua transformaçlo concreta. E, doutro lado, um dizer ao futuro no qual o pessimismo é um ensinamento contra o descaso antiético e acritico que perpassa relaçóes entre seres humanos e entre eles e instituiçōes e a natureza. 